\title{
A STUDY ON THE STANDARDIZATION PARAMETERS OF CASSIA ANGUSTIFOLIA
}

\author{
PRAGATI KHARE ${ }^{1 *}$, KAMAL KISHORE ${ }^{2}$, DINESH KUMAR SHARMA ${ }^{3}$
}

${ }^{1}$ Department of Pharmacy, Shri Ram Murti Smarak, C.E.T., Bareilly, Uttar Pradesh, India. ${ }^{2}$ Department of Pharmacy, M.J.P. Rohilkhand University, Bareilly, Uttar Pradesh, India. ${ }^{3}$ Department of Pharmacy, Devsthali Vidyapeeth College of Pharmacy, Rudrapur, Uttarakhand, India. Email: pragatikhare10@gmail.com

Received: 09 March 2017, Revised and Accepted: 19 April 2017

\section{ABSTRACT}

Objective: Now-a-days, the herbal medicines are much efficient for the treatment of various disorders as they have minimal side effects in comparison to the allopathic medicines. Cassia angustifolia, commonly called Senna belongs to the family Leguminosae and is a well-known laxative throughout the world. Senna is mostly found in Tirunelveli, Madurai, and Ramnathpuram districts of Tamil Nadu. Carbohydrates, tannins, alkaloids, flavonoids, and amino acid are the important chemical constituents of $C$. angustifolia. The objectives of the present study are to investigate various pharmacognostic, phytochemical analysis, and pharmacological properties of $C$. angustifolia.

Methods: The powdered drug was used for estimating the loss on drying, ash values, fluorescence studies, chemical tests, and extractive values. Macroscopic and microscopic studies were also performed.

Results: The transverse section (T.S). of leaf showed isobilateral structure along with paracytic stomata, nonlignified unicellular trichomes with warty walls, and fibrovascular bundle. The fluorescence characteristics of leaf powder were studied both in visible light and ultraviolet (UV) light (254 $\mathrm{nm}$ and $365 \mathrm{~nm}$ ) after treatment with various reagents. Senna is composed of carbohydrates, tannins, alkaloids, flavonoids, and amino acid. It was reported that the total ash value was $11.23 \pm 0.25 \mathrm{w} / \mathrm{w}$. The acid insoluble ash value was $1.4 \pm 0.1 \% \mathrm{w} / \mathrm{w}$. Water soluble, ethanol, methanol, petroleum ether, and chloroform extractive values were $16.6 \pm 0.26 \% \mathrm{w} / \mathrm{w}, 3.7 \pm 1.75 \% \mathrm{w} / \mathrm{w}, 0.83 \pm 0.05 \% \mathrm{w} / \mathrm{w}, 1.6 \pm 0.1 \% \mathrm{w} / \mathrm{w}$, and $3.2 \pm 0.25 \% \mathrm{w} / \mathrm{w}$, respectively.

Conclusion: The main pharmacological activities of Bauhinia variegata are anthelmintic, antiulcer, antitumor, antimicrobial, antidiabetic, antiinflammatory, antigoitrogenic, and hepatoprotective. The present investigation provides the information on its pharmacognostic, phytochemical analysis, and pharmacological properties.

Keywords: Senna, Sennosides, Laxative, Flavonoids, Ash value.

(C) 2017 The Authors. Published by Innovare Academic Sciences Pvt Ltd. This is an open access article under the CC BY license (http://creativecommons. org/licenses/by/4. 0/) DOI: http://dx.doi.org/10.22159/ajpcr.2017.v10i7.18394

\section{INTRODUCTION}

Cassia angustifolia (senna) and it belongs to Leguminosae family. Senna is used for the treatment of constipation mostly in Eastern and Western countries $[1,2]$. The laxative activity of senna is due to the presence of two anthraquinone glycosides, i.e., sennoside A and sennoside B. C. angustifolia is also composed of rhein-8-diglucoside, sennosides C and D, rhein, rhein-8-glucoside, aloe-emodin and anthrone diglucoside, and napthalene glycosides such as tinnevellin glycoside and 6-hydroxy musizin glycoside, flavonoid (kaempferol), phytosterols, resin, and calcium oxalate $[3,4]$. It was reported that the first variety of senna was found along the Nile River in Egypt and Sudan. Commercially, it is cultivated in Kutch (Gujarat) and Jodhpur (Rajasthan), India. It can be grown as a perennial crop for duration of about 2-3 years [2]. The Flowers and leaves of Cassia angustifolia are represented in (Fig. 1). The leaves of Cassia angustifolia are represented in (Fig. 2). The plant of Cassia angustifolia is represented in (Fig. 3).

Taxonomical classification [6]

\begin{tabular}{ll}
\hline Kingdom & Plantae \\
\hline Sub division & Spermatophyta \\
Division & Magnoliophyta \\
Class & Magnoliopsida \\
Sub class & Rosidae \\
Order & Fabales \\
Family & Fabaceae/Leguminoceae \\
Genus & Cassia \\
Species & Angustifolia \\
\hline
\end{tabular}

Synonyms [6]

\begin{tabular}{ll}
\hline Sanskrit & Swarn patti \\
\hline Hindi & Sanai \\
Telugu & Sunamukhi \\
Tamil & Nilavarai, nelavakai \\
Malayalam & Sunnamukki, connamukki \\
Kannada & Nela tangedu \\
Gujarati & Nat ki sana \\
\hline
\end{tabular}

\section{Medicinal uses}

C. angustifolia is used for the treatment of splenic enlargements, anemia, typhoid, cholera as a febrifuge, as blood purifier, as an anthelmintic, and as remedy for constipation [6]. Senna has been already included in I.P. as a purgative due to the presence of rhein, aloe-emodin, kaempferol, and isormamnetin [7].

\section{Macroscopic characters}

Senna leaves are delicate and grayish-green. The pods and fruits are oblong in shape. The compound leaves are composed of 5-8 pairs of ovallanceolate leaflets $(2.5 \mathrm{~cm} \times 1.5 \mathrm{~cm})$. Flowers are large and yellow. Senna produces medium-sized pods. The seeds are flat and yellowish [2]. The leaflets possess short and stout petioles which may be rarely broken. The length of leaflets is about $1.5-6.0 \mathrm{~cm}$ long and width is $0.5-1.5 \mathrm{~cm}$. They have a specific odor and mucilage-like/slightly bitter taste $[4,8]$.

\section{METHODS}

The leaves of $C$. angustifolia were collected from Guttumal and Company, Shivaji Marg, Bareilly, Uttar Pradesh, India and identified (specimen 
number-RU/PS/2016/415) by Professor A.K. Jaitly, HOD, Department of Plant Science, Mahatma Jyotiba Phule Rohilkhand University, Bareilly, Uttar Pradesh.

Powdered drug was used for moisture content, ash values, swelling index, and fluorescence studies were carried out by treating $0.5 \mathrm{~g}$ of powdered drug with different reagents and observation in color was made in visible light, UV light of short (254 nm), and long wavelength (365 nm) under UV chamber. Photomicrography was performed using Olympus C7070 camera [9]

\section{RESULTS AND DISCUSSION}

Microscopical examination of leaf

The T.S. of leaf showed isobilateral structure alongwith paracytic stomata, nonlignified unicellular trichomes with warty walls, fibrovascular bundle lined with abundant prisms of calcium oxalate, 4-5 tier palisade, and sclerenchyma. The transverse section of leaf of Cassia angustifolia is represented in (Fig. 4).

\section{Pharmacognostic evaluation of the plant}

The plant material was used for quantitative determination of physicochemical values. ash values, loss on drying, and extractive values of Cassia angustifolia are represented in Table 4.

\section{Phytochemical screening}

The dried leaves were powdered and extracted with petroleum ether, chloroform, ethanol, and water in soxhlet apparatus. The percentage yield was analyzed. The phytochemical tests were performed for the estimation of alkaloids, glycosides, flavonoids, and tannins in various plant extracts and resulted in the presence of carbohydrates, gums, proteins, alkaloid, saponins, flavonoids, and tannins and results are given in Table 1.

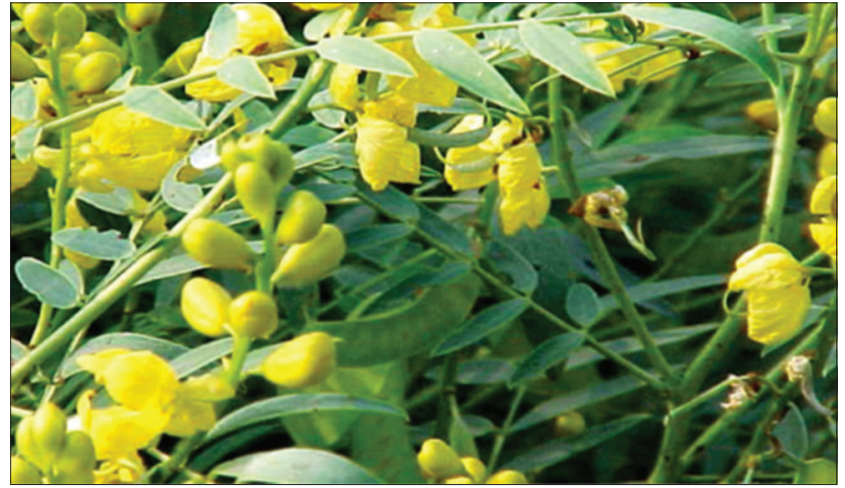

Fig. 1: Flowers and leaves of Cassia angustifolia

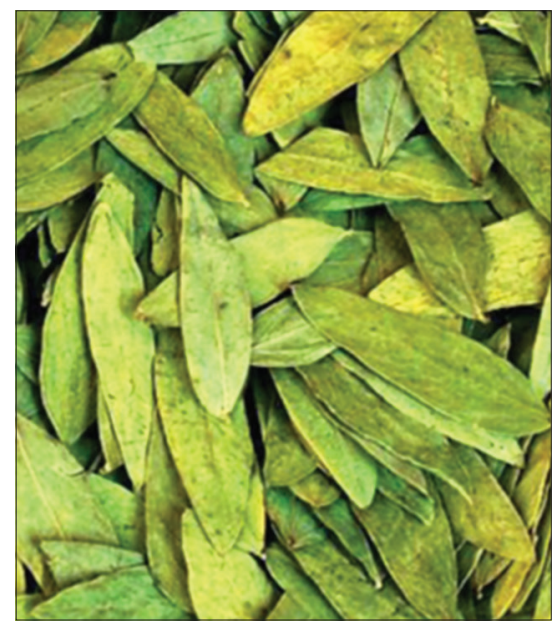

Fig. 2: Leaves of senna
Fluorescent studies of powder drugs

The fluorescence characteristics of leaf powder were studied both in visible light and UV light (254 nm and $365 \mathrm{~nm}$ ) after treatment with various reagents and is represented in Table 2 [10-12]

The physiochemical parameters of leaf of $C$. angustifolia Linn are tabulated in Table 3. The loss on drying at $105^{\circ} \mathrm{C}$ in leaf was found to be $1.90 \%$. Total ash value of leaf represents minerals and earthy materials attached in the plant material. It was reported that the total ash value was $11.2 \%$. The acid insoluble ash value was $1.5 \%$. The watersoluble ash value represents the presence of acids, sugar, and inorganic compounds and was found to be $4.7 \%$. The results are given in Table 3 .

\section{CONCLUSIONS}

Preliminary phytochemical and physicochemical investigations of C. angustifolia were performed in this study. These parameters are necessary for the identification of drugs and investigation of the bioactive constituents in medicinal herbs [13]. The presence of various chemical constituents in $C$. angustifolia may be a potential cause of treatment of various disorders. The quality of the plant can be estimated by determining the physical parameters. These investigations are of

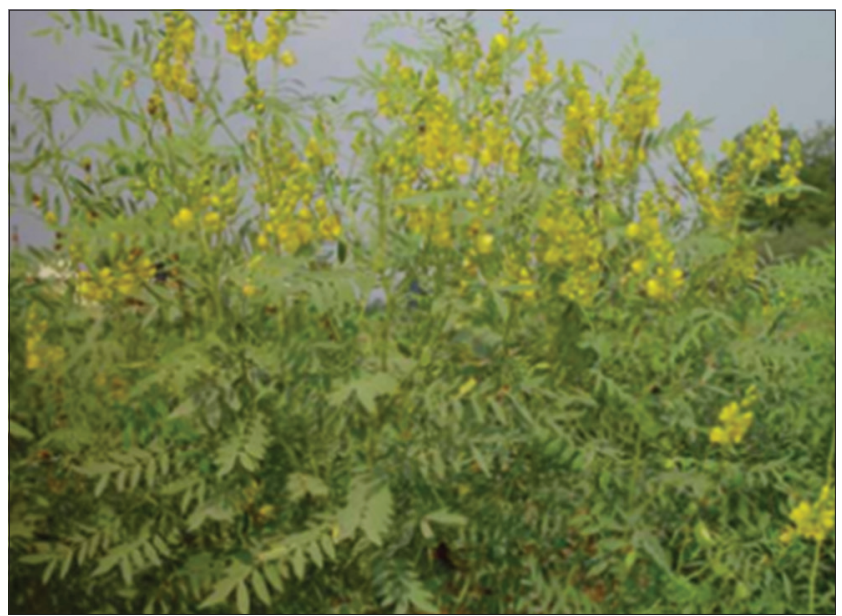

Fig. 3: Plant of Cassia angustifolia

Geographical source: Senna is mostly found in Tirunelveli, Madurai, and Ramnathpuram districts of Tamil Nadu. It is cultivated in Kadapa District of Andhra Pradesh, Rajasthan, and Gujarat State [5].

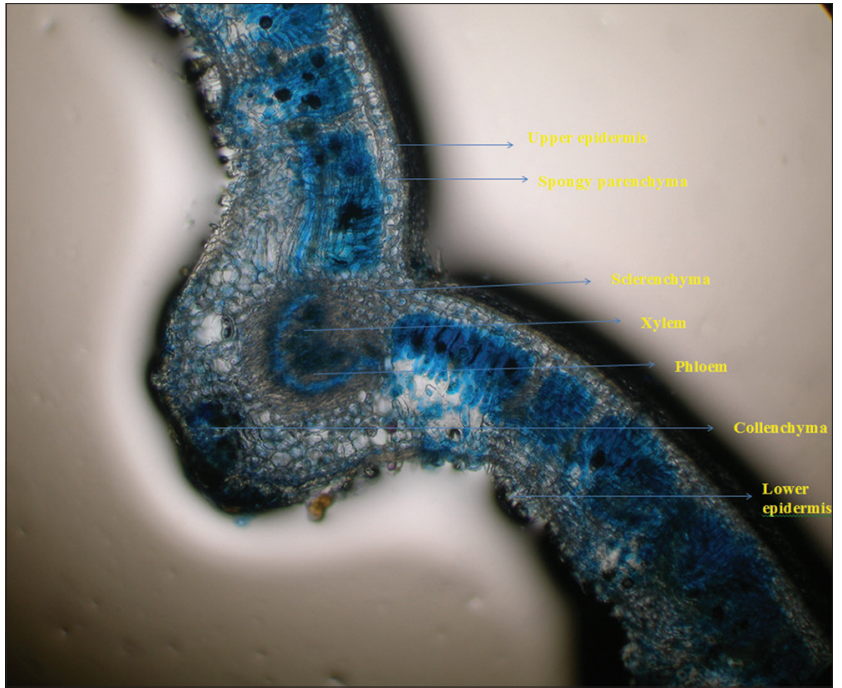

Fig. 4: The transverse section of leaf of Cassia angustifolia 
Table 1: Chemical tests

\begin{tabular}{|c|c|c|c|c|c|}
\hline Phytochemical tests & Petroleum ether & Methanol & Water & Ethanol & Chloroform \\
\hline \multicolumn{6}{|l|}{ Carbohydrates } \\
\hline Molish test & + & + & + & + & - \\
\hline Fehling's test & - & + & - & + & - \\
\hline Benedict's test & - & + & - & + & - \\
\hline Barfoed's test & - & - & - & - & + \\
\hline \multicolumn{6}{|l|}{ Proteins } \\
\hline Biuret test & + & + & + & + & - \\
\hline Xanthoprotein test & + & + & + & - & - \\
\hline \multicolumn{6}{|l|}{ Amino acids } \\
\hline Ninhydrin test & + & + & + & + & + \\
\hline Tyrosin test & - & - & - & + & - \\
\hline Cystein test & - & - & - & + & - \\
\hline \multicolumn{6}{|l|}{ Triterpenoid } \\
\hline Noller's test & - & + & + & - & - \\
\hline \multicolumn{6}{|l|}{ Steroid } \\
\hline \multicolumn{6}{|l|}{ Cardiac glycosides } \\
\hline Baljet's test & + & + & + & + & + \\
\hline Legal's test & - & + & - & + & - \\
\hline Keller-Killiani test & - & + & + & + & - \\
\hline \multicolumn{6}{|l|}{ Anthraquinone glycosides } \\
\hline Borntrager's test & - & - & - & - & - \\
\hline Modified Borntrager's test & - & - & - & - & - \\
\hline \multicolumn{6}{|l|}{ Saponin glycosides } \\
\hline Foam test & + & + & + & + & + \\
\hline \multicolumn{6}{|l|}{ Cyanogenetic glycosides } \\
\hline $\mathrm{Na}$ - picrate test & + & + & + & + & + \\
\hline \multicolumn{6}{|l|}{ Flavonoids } \\
\hline Shinoda test & - & + & + & + & - \\
\hline Lead acetate & - & + & + & + & - \\
\hline $\mathrm{NaOH}$ & + & + & + & + & - \\
\hline \multicolumn{6}{|l|}{ Alkaloids } \\
\hline Hager's test & - & + & + & + & - \\
\hline \multicolumn{6}{|l|}{ Tannins } \\
\hline $5 \% \mathrm{FeCl}_{3}$ & + & + & - & + & - \\
\hline Lead acetate & - & + & + & + & + \\
\hline Dil. $\mathrm{HNO}_{3}$ & - & + & + & + & - \\
\hline Acetic acid & - & + & + & + & - \\
\hline
\end{tabular}

Table 2: Fluorescence activity of $C$. angustifolia leaves

\begin{tabular}{|c|c|c|c|}
\hline \multirow[t]{2}{*}{ Material/treatment } & \multicolumn{3}{|c|}{ Observation under UV cabinet } \\
\hline & Visible light & Short UV $254 \mathrm{~nm}$ & Long UV $365 \mathrm{~nm}$ \\
\hline Drug powder as such & Muddy green & Green & Light brown \\
\hline Powder treated with concentrated $\mathrm{HCl}$ & Golden & Dark green & Blackish green \\
\hline Powder treated with 1 molar $\mathrm{NaOH}$ in water & Dark green & Black & Brownish black \\
\hline Powder treated with concentrated ethanol & Golden & Green & Light green \\
\hline Powder treated with concentrated acetic acid & Golden & Dark green & Light green \\
\hline Powder treated with $5 \% \mathrm{FeCl}_{3}$ & Pine forest & Dark green & Dark green \\
\hline Powder treated with concentrated benzene & Golden & Green & Reddish green \\
\hline Powder treated with methanol & Golden & Pine forest & Green \\
\hline Powder treated with $1 \mathrm{M} \mathrm{H}_{2} \mathrm{SO}_{4}$ & Red & Reddish brown & Brown \\
\hline Powder treated with concentrated $\mathrm{HNO}_{3}$ & Red & Reddish black & Black \\
\hline Powder treated with chloroform & Golden & Dark brown & Reddish brown \\
\hline Powder treated with distilled water & Green & Greenish brown & Brown \\
\hline
\end{tabular}

great importance for carrying out the revalidation and estimation of its other pharmacological activities. It was concluded from the phytochemical study that the ethanolic extract contains flavonoids, glycosides, carbohydrates, and tannins which are responsible for various pharmacological activities such as anti-inflammatory, chemoprotective activity, antioxidant, antidiabetic, antianxiety, and antidepressant.

\section{ACKNOWLEDGMENTS}

We are thankful to the Management of Department of Pharmacy, Shri Ram Murti Smarak, C.E.T., Bareilly, Uttar Pradesh, India for providing chemicals and other infrastructure for doing this research work. The work is dedicated to my guide and co-guide. 
Table 3: Physiochemical parameters

\begin{tabular}{|c|c|c|c|c|}
\hline Parameters & Values $(\% \mathrm{w} / \mathrm{w})$ & Values $(\% \mathrm{w} / \mathrm{w})$ & Values $(\% \mathrm{w} / \mathrm{w})$ & Mean \pm SD $(\% \mathrm{w} / \mathrm{w})$ \\
\hline Total ash value & 11.2 & 11.5 & 11.0 & $11.23 \pm 0.25$ \\
\hline Water - insoluble ash value & 6.5 & 6.75 & 6.1 & $6.45 \pm 0.32$ \\
\hline Water - soluble ash value & 4.7 & 4.5 & 4.2 & $4.46 \pm 0.25$ \\
\hline Acid- insoluble ash value & 1.5 & 1.3 & 1.4 & $1.4 \pm 0.1$ \\
\hline Loss on drying & 1.90 & 1.8 & 1.9 & $1.86 \pm 0.05$ \\
\hline
\end{tabular}

UV: Ultraviolet, SD: Standard deviation

Table 4: Extractive values of $C$. angustifolia $\mathrm{L}$

\begin{tabular}{|c|c|c|c|c|}
\hline Solvent & Extractive value $(\% \mathrm{w} / \mathrm{w})$ & Extractive value $(\% \mathrm{w} / \mathrm{w})$ & Extractive value $(\% \mathrm{w} / \mathrm{w})$ & Mean \pm SD $(\% \mathrm{w} / \mathrm{w})$ \\
\hline Water & 16.5 & 16.9 & 16.4 & $16.6 \pm 0.26$ \\
\hline Ethanol & 3.8 & 3.9 & 3.6 & $3.7 \pm 1.75$ \\
\hline Chloroform & 0.8 & 0.9 & 0.8 & $0.83 \pm 0.05$ \\
\hline Petroleum-ether & 1.5 & 1.6 & 1.7 & $1.6 \pm 0.1$ \\
\hline Methanol & 3.0 & 3.2 & 3.5 & $3.2 \pm 0.25$ \\
\hline
\end{tabular}

C. angustifolia: Cassia angustifolia, SD: Standard deviation

\section{REFERENCES}

1. Wallis TE, editor. Text Book of Pharmacognosy. $5^{\text {th }}$ ed. London: United States Pharmacopoeia; 2004. p. 136-8.

2. Balasankar D, Vanilarasu K, Preetha PS, Rajeswari S, Umadevi M, Bhowmik D. Senna-A medical miracle plant. J Med Plants Stud 2013;1(3):41-7.

3. Kokate CK, Purohit AP, Gokhale SB, editors. Pharmacognosy. $25^{\text {th }}$ ed. India: Nirali Prakashan; 2003. p. 157-60.

4. Agarwal V, Bajpai M. Pharmacognostical and biological studies on senna and its products: An overview. Int J Pharm Bio Sci 2010;6(2):1-10.

5. Sultana S, Ahmad M, Zafar M, Khan MA, Arshad M. Authentication of herbal drug Senna (Cassia angustifolia Vahl.): A village pharmacy for Indo-Pak subcontinent. Afr J Pharm Pharmacol 2012;6(30):2299-308.

6. Deshpande HA, Bhalsing SR. Recent advances in the phytochemistry of some medicinally important Cassia species: A review. Int J Pharm Med Bio Sci 2013;2(3):60-78.

7. Khare CP. Indian Medicinal Plants: An Illustrated Dictionary.
New York: Springer; 2007

8. Handa SS, Kapoor VK, editors. Text Book of Pharmacognosy. $2^{\text {nd }}$ ed. Delhi: Vallabh Prakashan; 2003. p. 80-3.

9. Sunita P, Jha S, Pattanayak SP. Anti-inflammatory and in-vivo antioxidant activities of Cressa cretica Linn. A halophytic plant. Middle East J Sci Res 2011;8(1):129-40.

10. Prasad V, Kadam R, Deoda S, Rakesh S. Pharmacognostic, phytochemical and physiochemical studies of Mimusops elengi Linn stem bark (Sapotaceae). Pharm Lett 2012;4(2):607-13.

11. Arulanandraj N, Gopal V. Phytochemical screening of roots extracts of Marva (Maerua oblongifolia). Int J Univ Pharm Life Sci 2011;1(2):282-93

12. Katara A, Pradhan CK, Tyagi AK, Singh P. Phytochemical investigation and antimicrobial activity of Leucas cephalotes Roth, Spreng whole herb. Pharm Chem 2010;2(4):284-96.

13. Yadav M, Chatterji S, Gupta SK, Watal G. Preliminary phytochemical screening of six medicinal plants used in traditional medicine. Int J Pharm Pharm Sci 2014;6(5):539-42. 